Acta Universitatis Nicolai Copernici • Pedagogika XL/2/2020

Nauki Humanistyczno-Społeczne • Zeszyt 452

DOI: http://dx.doi.org/10.12775/AUNC_PED.2020.012

Maria Szczepska-Pustkowska

Instytut Pedagogiki, Wydział Nauk Społecznych

Uniwersytet Gdański

https://orcid.org/0000-0002-8307-6566

\title{
„DZIECI NAZNACZONE ŚMIERCIĄ", \\ CZYLI O DZIECIĘCEJ TOŻSAMOŚCI (TRAGICZNIE) \\ ZERWANEJ W ŚWIETLE KONCEPCJI \\ ZNIEWOLONEGO DZIECIŃSTWA
}

"Children Marked by Death":

About a (Tragically) Broken Child's Identity

in the Light of the Concept of Enslaved Childhood

\begin{abstract}
Abstrakt
Adina Blady-Szwajger stwierdziła w swoim pamiętniku, że pisać o dzieciach jest najtrudniej, ponieważ trudno znaleźć słowa, które „krzyczą”, oraz że pisać o dzieciach w czasie wojny oznacza przywoływać ich cierpienie, pracę ponad siły i śmierć ${ }^{1}$. Prezentowany tekst ma na celu - po pierwsze - przypomnienie ludzkich historii - historii dzieci Holocaustu, o których nie należy zapominać. Po drugie - jest próbą odczytania w ich kontekście dzieciństwa zniewolonego. Pierwszy ze wskazanych celów dotyczy analizy wybranych dziecięcych świadectw diarystycznych z okresu II wojny światowej, związanych z zerwaniem pierwotnej tożsamości i „(w)socjalizowaniem” w nową tożsamość (pol-
\end{abstract}

1 Por. A. Blady-Szwajger, I więcej nic nie pamiętam, Warszawa 2010. 
ską - katolicką). Wspomniane źródła traktuję jako przyczynek do próby zrozumienia procesu wykorzeniania dziecka żydowskiego z jego dotychczasowej tożsamości, konstruowania na jej miejsce nowego wzoru, a w rezultacie pedagogicznie znaczącego biograficznego doświadczenia zerwania ciągłości tożsamości / rozdwojenia tożsamości. Drugi ze sformułowanych celów jest związany z osadzeniem tej problematyki na tle refleksji pedagogicznej, dla której jedną ze znaczących kategorii jest przemoc symboliczna, ukierunkowana na zmianę ludzkiej tożsamości.

Słow a kluc zowe : tożsamość dziecięca, tożsamość zerwana, zniewolone dzieciństwo, przemoc symboliczna

\begin{abstract}
Adina Blady-Szwajger stated in her diary that writing about children is the most difficult because she cannot find words that "scream", and that to write about children in wartime means recalling their suffering, overworking and death. The presented text is an attempt to overcome this difficulty. It aims first of all - to remind people's stories - the stories of children of the Holocaust, who should not be forgotten. Secondly, it is an attempt to read the captive childhood in their context. The first of the indicated goals concerns the analysis of selected children's diarist testimonies from the period of World War II, related to the breaking of the original identity and "socialization" into a new (Polish - Catholic) identity. I treat the aforementioned sources as a contribution to an attempt to understand the process of uprooting a Jewish child from its previous identity, constructing a new model in its place, and as a result, a pedagogically significant biographical experience of breaking the continuity of identity / split identity. The second of the formulated goals is related to the reference of this issue against the background of pedagogical reflection for which symbolic violence, aimed at changing human identity has become one of the significant categories.
\end{abstract}

Keywords: children's identity, broken identity, enslaved childhood, symbolic violence 


\section{Tożsamość}

Tluczowa dla niniejszego tekstu kategoria tożsamości nie doczeka- ła się jak dotąd jednolitej definicji. Mimo że jej początki sięgają odwiecznego pytania Kim jestem?, to jej głębia od starożytności po stanowiska współczesne była i jest różna. Literatura przedmiotu traktuje tożsamość jako: zjawisko ${ }^{2}$, fenomen ${ }^{3}$ lub konstrukt ${ }^{4}$, akcentując wieloznaczność i złożoność tego terminu oraz wskazując wielość koncepcji teoretycznych, które pozwalają na deskrypcję, analizę i interpretację tej problematyki.

Komentując poszukiwania terminologiczne, Aldona Jawłowska zauważa, że tożsamość należy traktować raczej jako postulat czy cel niż jako właściwość, sytuację czy stały stan posiadania. Tak rozumiana tożsamość obejmuje raczej proces niż stan będący jego rezultatem. Akcent należy zatem położyć na pytanie, w jaki sposób tożsamość się tworzy i zmienia, a nie na to, czym jest ${ }^{5}$.

Niezależnie od tego, w jaki sposób jest ona postrzegana i definiowana, wśród zainteresowanych nią badaczy istnieje zasadnicza zgodność co do faktu, że tożsamość nie jest „darem natury”. Zygmunt Bauman zauważa, że „(t)ożsamości nie dostaje się ani w prezencie, ani z wyroku bezapelacyjnego; jest ona czymś, co się konstruuje i co można (przynajmniej w zasadzie) konstruować na różne sposoby"6. Powstaje ona w procesie socjalizacji - w aktach społecznego rozpoznania - jest społecznie „nadawana”, wymaga dość regularnie społecznego potwierdzania i w podob-

2 Por. G. Babiński, Pogranicze polsko-ukraińskie. Etniczność, zróżnicowanie religijne, tożsamość, Kraków 1997; tenże, Metodologiczne problemy badań etnicznych, Kraków 1998.

3 Por. J. Nikitorowicz, Pogranicze. Tożsamość. Edukacja międzykulturowa, Białystok 1995.

4 Por. K. Warmińska, Tatarzy polscy. Tożsamość religijna i etniczna, Kraków 1999.

5 A. Jawłowska, Tożsamość na sprzedaż, w: Wokót problemów tożsamości, red. A. Jawłowska, Warszawa 2001, s. 54.

6 Z. Bauman, Ponowoczesne wzory osobowe, „Studia Socjologiczne”, 1993 nr 2(200), s. 8. 
ny sposób bywa ona zmieniana (a nawet odbierana) ${ }^{7}$. A skoro tak, to tożsamość (społeczno-kulturowa) jednostki może oznaczać „[...] procesy umiejscawiania siebie przez jednostkę $\mathrm{w}$ ramach pewnego symboliczno-strukturalnego układu odniesienia, dokonujące się poprzez procesy wewnętrznej i zewnętrznej identyfikacji, czyli (a) podkreślanie swojego związku z określonymi kategoriami w owym polu społeczno-symbolicznym (identyfikacja, utożsamianie się) oraz odrębności względem innych kategorii w tym polu, (b) definiowanie jednostki przez innych (identyfikacja zewnętrzna, czyli społeczna kategoryzacja), a także (c) strategie odpowiedzi jednostki na te zewnętrzne określenia, które to strategie prowadzić mogą do zmiany lub utrwalenia wcześniejszej autoidentyfikacji jednostki"8.

Nie sposób zatem mówić o tożsamości bez uwzględnienia społecznego i kulturowego kontekstu jej tworzenia / powstawania ani o tożsamości (społecznej) z pominięciem jej wymiaru subiektywno-świadomościowego ${ }^{9}$. Sprawia to z jednej strony, że wszystkie osobiste autoidentyfikacje jednostki, które zapewniają jej poczucie ciągłości i niezmienności własnej osoby, sięgają swoimi korzeniami do dostępnych jej wzorców kulturowych i mechanizmów społecznych konstruowania własnej indywidualnej podmiotowości. Z drugiej zaś - wskazuje to, że jednostka wykorzystuje społeczno-symboliczne zasoby zastane w otoczeniu, które pozwalają jej na (auto)identyfikację $\mathrm{z}$ nim $\mathrm{w}$ procesie socjalizacji ${ }^{10}$. W rezultacie jej identyfikacja z grupą (tożsamość społeczna / publiczna) może stanowić ważny element indywidualnego projektu (tożsamości osobistej / prywatnej), który może się ukształtować w procesie socjalizacji pod wpływem wzorców społeczno-kulturowych przejętych (bardziej lub mniej świadomie) z otoczenia ${ }^{11}$.

Wnikając głębiej w mechanizm socjalizacji, dostrzegamy, że w procesie tym (zwłaszcza we wczesnym jego etapie) dziecko nie ma możliwości

7 P.L. Berger, Zaproszenie do socjologii, Warszawa 1988, s. 107-108.

8 M. Starnawski, Socjalizacja i tożsamość żydowska $w$ Polsce powojennej. Narracje emigrantów z pokolenia Marca' 68, Wrocław 2016, s. 88.

9 Tamże, s. 87.

10 Tamże.

11 Tamże. 
wyboru tzw. znaczących innych, których spotyka w swoim otoczeniu. Przychodząc na świat, wkracza ono w zastaną ich grupę (np. rodzice, opiekunowie, najbliższa rodzina) i musi ich zaakceptować. Tych znaczących innych dziecko nie wybiera, ponieważ możliwość takiego wyboru po prostu nie istnieje. $\mathrm{Z}$ tego faktu wynikają poważne konsekwencje: (a) identyfikacja dziecka z rodzicami (jako znaczącymi innymi) przebiega automatycznie; (b) z tej przyczyny dokonywana przez nie internalizacja ich konkretnej rzeczywistości jest nieunikniona, rodzice bowiem jako znaczący inni „podają” dziecku jako obiektywną rzeczywistość skonstruowany i przefiltrowany przez siebie obraz świata i ludzi wraz ze swoimi tego świata definicjami; (c) w sytuacji braku wyboru dziecko uwewnętrznia świat rodziców jako jedyny istniejący i jedyny, jaki daje się pomyśleć, co oznacza, że przychodzi ono na świat i wzrasta nie tylko w jakiejś konkretnej grupie / konkretnej sytuacji społecznej, ale także i przede wszystkim w konkretnej, skonstruowanej przez tę grupę rzeczywistości ${ }^{12}$.

Internalizując ten „zadany” świat, od najwcześniejszych lat życia dziecko uczy się, że jest tym, kim jest nazywane, oraz że każde (nadane mu) imię wiąże się z przypisaniem go do określonego miejsca w świecie, które może być uważane za własne i które gwarantuje „przynależność do", zapewniając elementarne poczucie bezpieczeństwa. W ten sposób konstytuuje się pierwszy świat dziecka, którego szczególną cechą jest trwałość, będąca wynikiem wspomnianych jego koniecznych związków z najwcześniej znaczącymi innymi. Przejrzystość tego świata, jednoznaczna w nim obecność ważnych innych oraz podawane przez nich definicje powodują, że zachowuje on ową szczególną przemożną realność i pozostaje światem własnym bez względu na to, jak daleko od niego odejdziemy w późniejszym życiu. Warto przy tym pamiętać, że doświadczenia okresu socjalizacji pierwotnej są znacznie silniej zakorzenione w świadomości dziecka niż te, które zdobywa ono w dalszych jej etapach ${ }^{13}$. Bywa, że stanowią one swoisty schemat odtwarzany w jej

12 P.L. Berger, T. Luckmann, Społeczne tworzenie rzeczywistości, Warszawa 1983, s. 212.

13 Tamże. 
strukturze ${ }^{14}$, gdyż „uczulają” człowieka w późniejszych okresach jego życia na pewne sytuacje, a „znieczulają” na inne. W ten sposób wyznaczają trajektorię jego życia i wykorzystywane przezeń strategie przystosowania. Zdarza się niejednokrotnie, że rodzaj, jakość dziecięcych doświadczeń i ich pamięć decydują o jakościach, ku którym dorosły ciąży nieświadomie w swoim życiu.

W istocie każdy człowiek przychodzi na świat w jakichś szczególnych okolicznościach społeczno-kulturowych (których nie wybiera i na które nie ma wpływu) - rodzi się w określonej rodzinie (która w chwili przyjścia dziecka na świat posiada określony „kształt i wnętrze”), w której doświadcza określonego klimatu emocjonalno-intelektualnego, w której kultywuje się określone wartości, normy, obyczaje, zwyczaje i tradycje, w której panuje określona religijność, wreszcie - bliscy posługują się określonym językiem itp. Decyduje to o treściach, jakie zapisują się w jego pamięci dzieciństwa, i tworzy specyficzne warunki społeczne i kulturowe, w których realizuje się jego autoidentyfikacja. Uczucia, wzory zachowań i ról społecznych, wzorce postaw wobec świata i innych, sposoby postrzegania, wyjaśniania i interpretacji tego, co człowieka otacza, wpisują się w niej od najwcześniejszych lat życia, tworząc w niej schemat, który nosi on w sobie już zawsze. To właśnie ten schemat powoduje, że człowiek ma skłonność (choć czyni to nieświadomie), by organizować swoje życie na podobieństwo tego, z czym spotkał się w dzieciństwie. W ten sposób dzieciństwo trwa w nim aktywnie, mimo że przekroczył już dawno jego próg w stronę dorosłości. Działa tu, jak się wydaje, reguła przymusu odtwarzania tego, co przeszłe, która zarazem tworzy jego tu-i-teraz i rzutuje na jego jutro.

Reguła ta zdaje się dotyczyć w sposób szczególny dzieciństwa zniewolonego. Pytania o tożsamość pojawiają się bowiem tym częściej, im bardziej staje się ona „[...] czymś zadanym, a nie danym z racji zajmowanego określonego miejsca w uporządkowanym i stabilnym świecie"15. W przypadku dzieciństwa zniewolonego mamy do czynienia z wymuszonym konstruowaniem tożsamości oraz możliwością jej wymuszonej konwersji polegającej na zmianie dotychczasowych odniesień

14 Tamże, s. 217.

15 A. Jawłowska, Tożsamość na sprzeda $\dot{z}$, dz. cyt., s. 51. 
identyfikacyjnych, różnicowaniu stopnia uznania i przywiązania do kojarzonych z daną kategorią identyfikacyjną treści. Odbywa się to w relacji do opresji, przemocy, a bywa - że nawet zagłady. Zygmunt Bauman podkreśla, że refleksja dotycząca tożsamości staje się szczególnie istotna, kiedy dochodzi do konfrontacji, do sytuacji zagrożenia, którą można przybliżyć, wykorzystując metaforę „[...] fortecy obleganej przez wroga"16. Zbliżony pogląd prezentuje Aldona Jawłowska, która przyczyny powrotów do problemu tożsamości upatruje $\mathrm{w}$ „[...] momencie utraty lub zmiany punktów odniesienia, pozwalających własną tożsamość określić”'17.

Tożsamość jako spostrzeganie identyczności własnej osoby pomimo upływu czasu wraz z poczuciem, że inni również uznają tę jedność i ciągłość osobowości, charakteryzują trzy ważne aspekty: poczucie tożsamości, autokoncepcja i zachowania ${ }^{18}$.

Poczucie tożsamości wywodzi się ze świadomości niepowtarzalności cech oraz spójności i ciągłości własnego „ja” w czasie i przestrzeni. Jego istotę stanowi przeświadczenie jednostki o związku między tym, kim była w przeszłości, a tym, kim jest aktualnie. Wspomniane przeświadczenie powstaje na podstawie autokoncepcji, oznaczającej zbiór cech, które jednostka identyfikuje jako ją opisujące. Ten aspekt tożsamości kształtuje się w wyniku uogólniania wiedzy o sobie, budowanej na podstawie sądów innych osób oraz własnych doświadczeń. Wreszcie, poczucie tożsamości i autokoncepcja znajdują realizację w specyficznym dla jednostki sposobie zachowania. Dodajmy, że poczucie tożsamości osobowej można rozpatrywać w dwóch dopełniających się wymiarach. Pierwszym z nich jest wymiar biograficzno-wertykalny, związany z osiąganiem temporalnej ciągłości (czyli poczucia związku między tym, kim się było w przeszłości, a tym, kim się jest obecnie i do czego się zmierza w przyszłości); drugim - jest wymiar społeczno-ho-

16 Z. Bauman, Ponowoczesne wzory osobowe, „Studia Socjologiczne”, $1993 \mathrm{nr} 2$, s. 7-8, a także: idem, Tożsamość jaka była, jest i po co?, w: Wokót problemów tożsamości, red. A. Jawłowska, Warszawa 2001, s. 8.

17 A. Jawłowska, Tożsamość na sprzeda $\dot{z}$, dz. cyt., s. 51.

18 M. Wróblewska, Kształtowanie osobowości w perspektywie rozwojowej i edukacyjnej, „Pogranicze. Studia Społeczne”, 2011 t. 17, s. 178. 
ryzontalny, związany z połączeniem elementów ,ja” w danym momencie czasu $^{19}$. Tożsamość można zatem postrzegać jako rzeczywistość istniejącą w świadomości ludzi, którzy w niej uczestniczą i tworzą ją, równocześnie poznając siebie i swoje możliwości w świecie, w którym wzrastają ${ }^{20}$.

Jerzy Nikitorowicz traktuje tożsamość jako „[...] spotkanie teraźniejszości z przeszłością i antycypowaną przyszłością"21 i dodaje, że jest ona „[...] całością konstrukcji podmiotu, które odnosi do siebie, do podstawowej potrzeby - potrzeby przynależenia, która wyraża się w bliskości, poczuciu więzi, zakorzenienia, stabilności, identyfikacji z dziedzictwem, dorobkiem przodków”22. Wyjaśnia, że „[...] pojęcie tożsamości wskazuje przede wszystkim na kontynuację w czasie pewnych cech czy pewnej «osobowości». [...] na fakt pozostawania ciągle tym samym, bycia kimś, kto jest tożsamy z sobą z przeszłości, a więc tożsamy ze swoimi przeszłymi wartościami, myślami, działaniami"23.

Takiej szansy na „pozostanie tożsamym z sobą z przeszłości” nie otrzymały od losu dzieci żydowskie określane jako „rasowo bezwartościowe" i dlatego naznaczone śmiercią za życia - dzieci, które wbrew swojej woli znalazły się w skrajnej sytuacji zniewolenia wywołanej wojną. Żyjąc w warunkach wysokiego ryzyka, bezustannie przeżywały niebezpieczeństwo przemocy i eskalowanych zagrożeń. Dobrze poznały smak związanych z tym tragedii, upokorzeń, cierpienia, ocierając się wielokrotnie o śmierć. Ustawiczne niebezpieczeństwo, bezsilność wobec istniejących zagrożeń, ich nieuchronność, nieznany czas ich trwania stały się codziennymi gośćmi w ich życiu. Ratując życie w sensie fizycznym, przeżywały zerwanie, a nawet śmierć dotychczasowej tożsamości.

19 Tamże, s. 178-179.

${ }^{20}$ F. Znaniecki, Nauki o kulturze: narodziny i rozwój, Warszawa 1971, s. 228.

21 J. Nikitorowicz, Pogranicze. Tożsamość. Edukacja międzykulturowa, dz. cyt., s. 68.

22 Tamże.

23 Tamże. 


\section{Dzieciństwo zniewolone}

W pajdocentrycznej wizji Ellen K. Key - szwedzkiej intelektualistki, pisarki, nauczycielki, pedagoga, krytyka wychowania przełomu XIX i XX stulecia i działaczki ruchu kobiecego, wiek XX został (w pedagogice) nazwany „wiekiem dziecka”24.

Rzeczywistość boleśnie zweryfikowała jednak tę utopijną wizję. Ani dziecko nie zmieniło świata, ani świat nie okazał się przyjazny dziecku. Wiek XX, wbrew nadziejom Key, nie tylko nie był stuleciem dziecka, ale paradoksalnie - okazał się stuleciem wymierzonym w dziecko. Nie oszczędzał dzieci, wypełniając doświadczane przez nie dzieciństwo przemocą we wszystkich jej odmianach i formach (że wspomnę tylko dwie wojny światowe, setki mniejszych, lecz krwawych wojen lokalnych na tle etnicznym, religijnym, ekonomicznym, wielkie i małe rewolucje prowadzące do znaczących transformacji społeczno-politycznych i ekonomicznych czy masowe rzezie całych społeczności). W stuleciu tym dziecko z niemego świadka historii przeobraziło się w jej aktywnego uczestnika. Stało się nie tylko ofiarą przemocy i zniewolenia, przedmiotem eksterminacji, lecz także jej aktywnym „aktorem” - żołnierzem, czasem również bezwzględnym oprawcą. Dzieci płaciły i nadal płacą za świat pełen przemocy, doświadczają jej, mogą ją powielać, przenosić i potęgować. W wieku XX różnorakie formy przemocy pochłonęły dzieci, ogarniając i naznaczając całe ich życie codzienne ${ }^{25}$.

Druga wojna światowa była pierwszą w historii wojną świadomie zwróconą przeciwko dzieciom ${ }^{26}$, które ginęły z całymi swoimi rodzinami lub w całkowitym osamotnieniu; były deportowane, stawały się więźniami obozów koncentracyjnych, łagrów i stalinowskich obozów resocjalizacyjnych. „Straty, które w latach II wojny światowej ponio-

24 Por. E.K. Key, Stulecie dziecka, Wydawnictwo Dwie Siostry, Warszawa 2006.

25 B. Smolińska-Theiss, Pedagogika pokoju, w: Pokój z dziećmi. Pedagogika chrześcijańska wobec zagrożeń rozwoju dziecka, red. B. Smolińska-Theiss, Warszawa 1999, s. 8-9.

${ }^{26}$ F. Tych, Przedmowa, w: Archiwum Ringelbluma. Konspiracyjne Archiwum Getta Warszawy, t. 2: Dzieci - tajne nauczanie $w$ getcie warszawskim, red. R. Sakowska, Warszawa 2000, s. V-VIII. 
sły dzieci i młodzież polska wskutek eksterminacji hitlerowskiej, były ogromne: - 2,025 mln dzieci straciło życie, w tym 600 tys. dzieci żydowskich, - 200 tys. dzieci zostało wywiezionych do Niemiec hitlerowskich w celach germanizacyjnych (z tego wróciło około 15\%), - 710 tys. małoletnich zostało skierowanych do przymusowych prac fizycznych, 1,5 mln polskich dzieci po II wojnie światowej było sierotami, półsierotami, a także dziećmi opuszczonymi (22\% całego młodego pokolenia Polaków), z czego 320 tys. dzieci wymagało natychmiastowej opieki w specjalistycznych placówkach wychowawczych, terapeutycznych oraz medycznych. Trzeba dodać, iż ogółem w Europie po II wojnie było ok. 13 mln sierot i półsierot [...]"27.

Materiały zgromadzone w Archiwum Ringelbluma zawierają zapis tragedii dzieci żydowskich żyjących w realiach gett. Odnajdujemy w nich świadectwa wskazujące, że zamieszkująca je ludność, która w nieludzkich warunkach walczyła o przetrwanie, szczególną troską starała się otaczać dzieci - osierocone, głodne i wynędzniałe, pozbawione opieki zdrowotnej, edukacji itp. Pomimo to około 150 tys. dzieci żydowskich zginęło w samym getcie warszawskim, część nie przeżyła transportów w wagonach bydlęcych do obozów koncentracyjnych, tysiące zginęło w obozach, te zaś, które przeszły przez obozy, do końca życia dźwigały tragiczny ciężar pamięci dzieciństwa i KZ-syndrom ${ }^{28}$.

Wydaje się, że nie sposób oddzielić losów dziecka od losów kraju, narodu, społeczności lokalnej czy rodziny. Co więcej, dzieci pozostają (nadal) albo własnością rodziców, albo totalitarnego państwa, co sprawia, że dzieciństwo można i należy postrzegać w kontekstach zawłaszczania / zawłaszczenia i zniewalania / zniewolenia. Dowodzą tego choćby wyniki analiz psychohistorycznych Lloyda de Mause'a, pod wpływem których pękł mit dzieciństwa jako raju ${ }^{29}$.

27 W. Theiss, Sieroctwo wojenne polskich dzieci (1939-1945). Zarys problematyki, „Przegląd Pedagogiczny”, 2012 nr 1(21), s. 80.

28 W. Theiss, Zniewolone dzieciństwo, Warszawa 1996, s. 20-22.

29 L. de Mause, The History of Childhood as the History of Child Abuse, „Aesthema: The Journal of the International Primal Association”, 1994 No. 11, s. 48-62. Autor, poszukując odpowiedzi na pytania o kategorię dzieciństwa i jej ewolucję w czasie, różnych kulturach, odmiennych porządkach społeczno-politycznych i ekonomicznych, do badań o charakterze historycznym wprowadził perspekty- 
Niebezpieczeństwo zniewalania występuje zwykle tam, gdzie w życiu społeczno-politycznym pojawia się przemoc (rozumiana jako „operowanie w starciu z mocą, czyli siłą przeważającą"30). Jej celem jest zniewolenie (uzależnienie woli słabszych od silniejszych), czemu służą bezpośrednie i pośrednie środki przemocy i zniewalania. Podczas gdy te pierwsze mają charakter militarny i często łączą się z eksterminacją fizyczną oraz presją moralną, drugie przybierają formę politycznych i/lub gospodarczych środków zniewalania, które za pośrednictwem organizacji lub struktur społecznych prowadzą do zniewolenia strukturalnego. Oba wspomniane rodzaje środków zniewalania i oba rodzaje zniewolenia wywołują degradację życia zniewolonych ${ }^{31}$.

Termin zniewolone dzieciństwo, wypracowany i wprowadzony do polskiej literatury pedagogicznej przez Wiesława Theissa, oznacza dzieciństwo przebiegające $\mathrm{w}$ toku skrajnych wydarzeń społeczno-politycznych. Próba odpowiedzi na pytanie o kształt i znaczenie dzieciństwa upływającego pod znakiem zniewalających warunków polega, jak pisze autor, na odtworzeniu pola zniewolenia, na które składają się trzy sfery - sfera zagrożenia, sfera dewastacji oraz sfera wyboru ${ }^{32}$.

Sferę zagrożenia tworzą warunki, które są źródłem upokorzenia, cierpienia, tragedii i które w przypadku skrajnym mogą prowadzić do fizycznego unicestwienia dziecka. Tym, co łączy wspomniane okoliczności, jest niebezpieczeństwo. Przybiera ono zwykle postać zewnętrznych warunków tzw. wysokiego ryzyka, które zwiększają prawdopodobieństwo wystąpienia przemocy, a odczuwane są jako zagrożenie. Theiss, za Brunonem Bettelheimem, grupę tego typu bodźców określa mianem „sytuacji skrajnej”, którą charakteryzuje ustawiczne niebezpieczeństwo, (poczucie) bezsilności wobec istniejących zagrożeń oraz odczu-

wę psychodynamiczną, która stworzyła nieznaną dotąd w badaniach historycznych możliwość wnikliwej analizy relacji między dorosłym i dzieckiem (jako wyrazicielem różnorodnych potrzeb). Zauważa ponadto, że ewolucja dzieciństwa od kazirodztwa do miłości i od molestowania do empatii, choć niezwykle powolna, trudna i nierówna, stała się niezależnym postępowym źródłem ewolucji socjokulturowej.

30 A. Grzegorczyk, Filozofia czasu próby, Paryż 1979, s. 63.

31 W. Theiss, Zniewolone dzieciństwo, dz. cyt., s. 15.

32 Tamże, s. 20-27. 
cie ich nieuchronności i nieznanego czasu ich trwania. Następstwa życia w warunkach wysokiego ryzyka mogą mieć charakter bezpośredni lub odroczony. Skrajna sytuacja może powodować np. skutki określane jako „zespół obozu koncentracyjnego” (KZ-syndrom), na który - poza określonymi następstwami somatycznymi - składają się m.in. opóźnienia w rozwoju intelektualnym, przypadki chorób psychicznych i psychonerwic itp. Niektóre z symptomów KZ-syndromu występują po czasie pod postacią następstw wtórnych (np. niski poziom wykształcenia, lęk przed kontaktami z innymi, niedostosowanie społeczne itp.). Sferę zagrożenia charakteryzuje ponadto sytuacja wysokiego stresu, która może się pojawić zarówno w czasie wojny, jak i w okresie głębokiej destabilizacji (politycznej, ekonomicznej czy społecznej - np. destabilizacji życia dziecka w dysfunkcjonalnej rodzinie) ${ }^{33}$.

Sfera dewastacji jest drugim zasadniczym obszarem pola zniewolonego dzieciństwa. Składają się na nią czasowe lub trwałe zmiany, zahamowania, odchylenia od normy, widoczne w psychofizycznym rozwoju jednostki oraz w jej społeczno-kulturowych relacjach $\mathrm{z}$ otoczeniem. Badania medyczne, psychologiczne, prawne itp. odsłaniają $\mathrm{w}$ obrębie tej sfery odmienne problemy będące następstwem traum przeżytych na skutek przemocy i zagrożenia. W przypadku pedagogicznego ich ujęcia przyjmuje się zwykle klasyczną perspektywę antropologiczną, która wyróżnia odniesienia człowieka do świata i rzeczy, do ludzi (jednostek / zbiorowości), do Boga (Tajemnicy) czy do samego siebie. Pragnąc uchwycić te wymiary psychiki, przedmiotem analiz należy uczynić formułowane przez dziecko obrazy, np. rodziców i domu rodzinnego, kraju, krzywd i cierpień, czy marzenia i plany dzieci. Jak zauważa Theiss, odtwarzanie sfery dewastacji zniewolonego dzieciństwa odsłania świat dzieci przedwcześnie dojrzałych, dzieci bez dzieciństwa, pozbawionych radości życia. To świat ludzi, którym przyszło zmierzyć się z kwestiami generalnymi, którzy poznali pytania o sens życia i śmierci ${ }^{34}$.

Trzecia ze sfer zniewolonego dzieciństwa, nosząca miano sfery wyboru, wiąże się nieuchronnie z wyborem określonych wartości, któ-

33 Tamże, s. 20-22.

34 Tamże, s. 22-24. 
re zaaprobowane i przyjęte, decydują o ludzkim myśleniu i działaniu. Taki wybór ujawnia miarę stosunku między człowiekiem i światem. Zapada on w sytuacjach granicznych / ekstremalnych, które wytyczają drogę człowieka i dalszy bieg jego życia. Tak rozumiana sfera wyboru rozciąga się między dwoma skrajnymi punktami: śmiercią i zwycięstwem. Theiss wyjaśnia, że w przypadku pierwszym chodzi zarówno o śmierć dosłowną, najgłębsze cierpienie, jak i zagrożenie indywidualnej czy zbiorowej tożsamości. Klęska przybiera tu także wiele innych postaci, jak bierność, aprobata zaistniałej sytuacji czy powielanie zachowań agresora. W przypadku drugim natomiast idzie o walkę, przeciwstawienie się zagrożeniu, przemocy, zakazowi i sankcjom. Stawką jest tu zwycięstwo nad złem i swoją słabością. Wybór ujawnia własne możliwości jednostki, pozwala uchwycić aprobowany przez nią system wartości czy wierność wobec nich. Sfera wartości może zatem pokazywać zarówno bezsilność, jak i moc osób poddanych zagrożeniu. Należy pamiętać, że sfera wyboru jest polem rozstrzygnięć bardzo trudnych, często niejednoznacznych. Podejmowane tu decyzje zapadają na różnych etapach sytuacji skrajnej - czasem na jej początku, innym znów razem u jej krańca. Raz więc wybór jest przyczyną, a raz skutkiem szerszych okoliczności. Bez względu jednak na to, kiedy zapadła określona decyzja, dopiero badanie sfery wyborów pozwala odpowiedzieć na pytanie o faktyczny zakres i skutki zniewolonego dzieciństwa, ponieważ to właśnie ten obszar przynosi informacje, skąd i jakie siły czerpały dzieci, by przetrwać sytuację skrajną i związane $\mathrm{z}$ nią zagrożenia i niebezpieczeństwa. Szczególne znaczenie sfery wyboru wynika z tego, że jest ona zarówno obiektem bezpośredniego ataku sił przemocy, jak i polem bezpośredniej obrony. Znane są przykłady, w których chodziło o celowe i planowe kształtowanie określonych systemów wartości i postaw (włącznie z całkowitą depersonalizacją dzieci i młodzieży). Zadanie to często realizowały specjalne placówki wychowania sierot lub dzieci siłą oderwanych od rodziców. W obu przypadkach wychowanie zastąpiono silną, prymitywną presją, opartą na zasadzie kary i nagrody ${ }^{35}$.

35 W. Theiss, Zniewolone dzieciństwo, dz. cyt., s. 24-27. 
Wokół sfery wyboru skupiają się szersze zagadnienia zniewolonego dzieciństwa, jak np. różne społeczne postaci sieroctwa wojennego: dzieci tułacze, dzieci bezdomne, dzieci frontowe, wojenne kidnaperstwo, czy wreszcie dzieci - ofiary eksterminacji (Holocaustu), którym poświęcam kolejną część tekstu.

\section{Tożsamościowa mimikra}

W historii XX wieku odnajdujemy wiele przypadków ludobójstwa. Jednak Holocaust - zagłada europejskich Żydów dokonana przez nazistów w czasie II wojny światowej - jest jedną z największych i najstraszniejszych tragedii współczesnego świata. Szacuje się, że doprowadziła do śmierci około sześciu milionów mężczyzn, kobiet i dzieci. Stanowiła a zamierzoną i zrealizowaną na niespotykaną dotąd skalę eksterminację wszystkich członków jednego narodu (od dzieci po starców), jego kultury i tradycji. „Widzę często wieczorem w ciemności [...] szeregi idących dobrych, niewinnych ludzi, z płaczącymi dziećmi, stale idą [...] bici i maltretowani, że aż prawie przy tym padają. Nikogo nie oszczędzają, starzy ludzie, dzieci, niemowlęta, kobiety w ciąży, chorzy, wszystko, wszystko idzie w pochodzie do śmierci. [...] A wszystko dlatego, że są Żydami"36 - pisze czternastoletnia Anna Frank.

Narzędziem metodologicznym, które wykorzystałam w celu „odczytania" pola zniewolenia dzieci żydowskich (a w rezultacie - ich gry o życie i tożsamość oraz zerwania tożsamości tych, które przeżyły piekło Holocaustu), jest omówiona wyżej idea zniewolonego dzieciństwa. Analizom poddałam natomiast wybrane świadectwa, których źródłem jest pamięć dzieciństwa dzieci Holocaustu, które przeżyły tamten przerażający czas Zagłady ${ }^{37}$.

36 Dziennik Anny Frank, Warszawa 1957, s. 56-57.

37 R. Szuchta, „Spotkani na drodze” w doświadczeniu dzieci żydowskich ukrywajacych się na polskiej wsi w trzeciej fazie zagłady (1942-1945), w: Dzieci wojny. Oświęcim, red. A. Bartuś, Oświęcim 2016, s. 165. „Relacje dzieci żydowskich gromadzono już w czasie wojny. Robili to współpracownicy Emanuela Ringelbluma skupieni w Tajnym Archiwum Getta Warszawskiego «Oneg Szabat». Wśród nich byli pedagodzy i nauczyciele szkół żydowskich, którym los dzieci był szczególnie 
Dziecięce pamiętniki i dzienniki stanowią wśród tekstów osób ocalałych z czasów Zagłady grupę osobną i wyjątkową. Początkowo szkoła historiografii tradycyjnej traktowała te świadectwa z dużą nieufnością, chociaż równocześnie były one skwapliwie zbierane już pod koniec II wojny światowej ${ }^{38}$. Dzieci okazały się przy tym nie tylko biernymi uczestnikami i świadkami Zagłady, lecz także autentycznymi i wiarygodnymi jej narratorami, którzy w swoich opowieściach nie manipulowali prawdą. Młodzi diaryści byli wrażliwymi i wnikliwymi obserwatorami otaczającego ich świata. Ich zapisy cechuje bezpośredniość i szczerość $\mathrm{w}$ formułowaniu sądów ${ }^{39}$. Analizując wspomniane zapiski, powstające często na bieżąco pod wpływem tragicznych wydarzeń, można dostrzec, że wszechobecne zagrożenie życia, uwięzienie w sytuacji granicznej i brak możliwości przewidzenia jej końca były podstawowymi wyznacznikami sytuacji egzystencjalnej ich autorów.

W swoich analizach, których celem było odtworzenie pola zniewolenia dzieci żydowskich, wykorzystałam jednak źródła o nieco odmiennym charakterze. Są to bowiem wspomnienia czasu Zagłady zapisane głęboko w pamięci dorosłych dzieci Holocaustu zebrane przez Magdę Łucyan w książce Dzieci getta. Ostatni świadkowie zagłady. Prawdziwe historie ${ }^{40}$, która ukazała się nakładem Wydawnictwa Znak Horyzont w 2021 roku. Sięgnęłam także (wspomagająco) do Dziennika Anny Frank oraz powieści autobiograficznej Jacka Kupera Dziecko Holocaustu ${ }^{41}$.

bliski. Zachęcali je do wypowiedzi na temat rodzin i ich wojennych losów. Kilkanaście takich kwestionariuszy, wypełnionych przez nastolatków [...] w getcie warszawskim, zachowało się do naszych czasów".

${ }^{38}$ Por. E. Malik, Doświadczenie graniczne utrwalone na kartach dzienników dzieci żydowskich, w: Dzieci wojny, red. A. Bartuś, Oświęcim 2016.

39 J. Leociak, Teksty wobec zagłady. (O relacjach z getta warszawskiego), Wrocław 1997, s. 25.

${ }^{40}$ M. Łucyan, Dzieci getta. Ostatni świadkowie zagłady. Prawdziwe historie, Kraków 2021. W książce tej pomieszczono pięć wstrząsających relacji dzieci Holocaustu: Krystyny Budnickiej, Mariana Kalwary, Katarzyny Meloch, Józefa Lipmana i Zofii Lubińskiej-Rosset.

${ }^{41}$ Dziennik Anny Frank, dz. cyt. Także tekst: J. Kuper, Dziecko Holocaustu, Warszawa 1995. 
Przystępując do analizy wskazanych materiałów, zdawałam sobie sprawę z faktu, że losy dzieci pochodzących z rodzin żydowskich od początku II wojny światowej do jej zakończenia były zróżnicowane. Raul Hilberg zaproponował ich zgrubny podział na cztery główne okresy, w których naziści konsekwentnie realizowali plan eksterminacji Żydów, szczególną wagę przykładając do wyniszczenia dzieci. „Pierwszym były początkowe restrykcje. Drugim było życie w getcie. Potem nastąpiły selekcje do deportacji bądź egzekucji. Wreszcie dzieci wymordowano"42 pisał autor. Jedynym i wystarczającym powodem ich unicestwienia był fakt, że urodziły się Żydami - jako „rasowo bezwartościowe”43 przychodziły one na świat z narodowościowym wyrokiem śmierci. Chociaż część dzieci żydowskich została uratowana przed Zagładą, to rachunek, jaki przyszło im za to zapłacić, był niezwykle wysoki. Na jednej szali znalazło się bowiem fizyczne unicestwienie, na drugiej zerwanie i radykalna przebudowa dotychczasowej tożsamości, która niosła wyrok śmierci.

Holocaust to doświadczenie graniczne ${ }^{44}$, sytuacja skrajna, której graniczność objawia się w wydarzeniach i praktykach przebiegających w warunkach wysokiego ryzyka wywołujących obezwładniający, niemający precedensu potencjał gwałtu i przemocy. Jej efektem jest radykalne zaburzenie podstaw dotychczasowego ładu cywilizacyjnego oraz destrukcja wartości, na których opiera się wspólnota ludzka.

42 R. Hilberg, Sprawcy. Ofiary. Świadkowie. Zagłada Żydów 1933-1945, Warszawa 2007, s. 209; M. Grądzka, Utracone dzieciństwo. Dziecko żydowskie w KL Płaszów, w: Żydowskie dziecko, red. A. Jeziorkowska-Polakowska, A. Karczewska, Lublin 2013, s. 171. Jednym z licznych tego przykładów może być likwidacja getta w Krakowie.

43 M. Śmigły, Bezwartościowe rasowo dzieci, https://en.tropicielehistorii.pl/ bezwartosciowe-rasowo-dzieci2/\#.YI16qz9R2Uk (dostęp: 25.04.2021).

44 E. Malik, Doświadczenie graniczne utrwalone na kartach dzienników dzieci żydowskich, dz. cyt., s. 180-186. 


\section{Tabela 1}

Pole zniewolonego dzieciństwa dzieci żydowskich

\begin{tabular}{l} 
Sfera zagrożenia \\
\hline 1. Eksterminacja pośrednia \\
(wyniszczanie Żydów w gettach \\
głodem, chorobami i przymuso- \\
wą pracą ponad siły). \\
2. Eksterminacja bezpośrednia: \\
likwidacja gett, akcje wysie- \\
dleńcze i deportacje do obozów \\
zagłady, mordy (tzw. Akcja \\
Reinhardt).
\end{tabular}

3. „Polowanie na Żydów” (Judenjagt), którzy próbowali ocalić życie (faza I - faszyści systematycznie przeszukiwali i wyłapywali ukrywających się na terenie opuszczonych gett i w ich pobliżu; faza II - trwająca do końca wojny: tropienie, wyłapywanie, grabienie, mordowanie ukrywających się Żydów).

4. Tułaczka (bezdomność, ukrywanie się, głód, doznania strachu, wyniszczającej pracy fizycznej, upokorzenia i samotności, lęk przed zdradą; obawa przed „szmalcownikami” itp.).

5. „Pustynia ludzka” (wymiar topograficzny, egzystencjalny, psychologiczny, duchowy*.

\section{Sfera dewastacji}

Przeżycia dzieci Holocaustu, powstały w sytuacji skrajnej w obliczu śmiertelnego zagrożenia.

\section{Szkody psychiczne:}

głęboko negatywny wpływ na intelekt, emocje, jak i na zachowanie społeczne jednostek; obecne w fundamentach ludzkiego myślenia i działania; kształtowały stosunek do ludzi, do samego siebie, do świata, do Boga itp..* Poobozowy KZ-syndrom ${ }^{\text {*t* }}$.

\section{Szkody tożsamościo-}

we: narodowościowe przypisanie piętna / stygmatu; zmaganie się z: „tożsamością zerwaną" („tożsamością zranioną", „tożsamością rozdwojoną,"****) i jej tragicznymi skutkami; tożsamość jako coś, co zabija (w sensie fizycznym i psychicznym / duchowym).

\section{Sfera wyboru (wartości)}

Skrajne punkty sfery wyboru: śmierć i zwycięstwo

\author{
(walka) ${ }^{* * * k * k}$.
}

\section{Strategie przetrwania} w środowisku nieznanym: zerwanie / przekształcenie tożsamości społeczno-kulturowej (przez: walencję / modyfikację, konwersję religijno-kulturową $a^{* * * * * * *}$ ), mimikra tożsamościowa (zmiana imienia i nazwiska, przyjęcie nowej genealogii życia; nauka zasad wiary katolickiej, w tym zachowań charakterystycznych dla katolików - aż do przyjęcia wiary katolickiej); „wtopienie” się na różne sposoby w tło społeczne (np. modyfikacja wyglądu); zerwanie $\mathrm{z}$ językiem (a tym samym $\mathrm{z}$ kulturą) pielęgnowanym w domu rodzinnym i opanowanie języka polskiego jako własnego i stojącej za nim kultury.

“ R. Szuchta, „Spotkani na drodze” w doświadczeniu dzieci żydowskich ukrywających się na polskiej wsi $w$ trzeciej fazie zagłady (1942-1945), dz. cyt., s. 161-175.

** W. Theiss, Sieroctwo wojenne polskich dzieci (1939-1945). Zarys problematyki, dz. cyt., s. 87.

*** Por. W. Theiss, Zniewolone dzieciństwo, dz. cyt.; R.C. Lukas, Dziecięcy płacz. Holokaust dzieci żydowskich i polskich $w$ latach 1939-1945, Poznań 2018; L. Bandura, Wpływ wojny na psychikę dzieci i młodzieży (fragmenty z rozprawy doktorskiej z 1950 roku), wstęp i oprac. Z. Kwieciński, Toruń 2004.

**:** Por. E. Goffman, Piętno. Rozważania o zranionej tożsamości, Gdańsk 2005.

**** Dzieci oskarżają, red. M. Hochberg-Mariańska, N. Gruss, Kraków-Łódź-Warszawa 1947, s. 20. „Dzieci żydowskie nie tylko ginęły, nie tylko kryły się i uciekały przed katem - dzieci żydowskie walczyły o swe życie na wszystkich frontach tej nierównej walki”.

***** Por. M. Starnawski, Socjalizacja i tożsamość żydowska w Polsce powojennej. Narracje emigrantów z pokolenia Marca' 68, dz. cyt. 
Tabela 1 (cd.)

\begin{tabular}{|c|c|c|}
\hline Sfera zagrożenia & Sfera dewastacji & Sfera wyboru (wartości) \\
\hline & $\begin{array}{l}\text { 3. Szkody emocjonalno-spo- } \\
\text { łeczne: głębokie poczucie } \\
\text { samotności, brak najbliż- } \\
\text { szych (śmierć najbliż- } \\
\text { szych), przeżycie ucieczki } \\
\text { i ukrywania się, nieufność } \\
\text { do ludzi (obawa i strach } \\
\text { przed udzielającymi } \\
\text { pomocy); utrata wiary, na- } \\
\text { dziei, rozpacz, najgłębsze } \\
\text { cierpienie we wszystkich } \\
\text { możliwych wymiarach. } \\
\text { 4. Szkody edukacyjne: brak } \\
\text { dostępu do edukacji / } \\
\text { opóźnienia w edukacji. } \\
\text { 5. Przedwczesna dojrza- } \\
\text { łość: dzieci przedwcześnie } \\
\text { wydoroślałe, które otarły } \\
\text { się o rzeczy ostateczne. }\end{array}$ & \\
\hline
\end{tabular}

Źródło: opracowanie własne na podstawie analizowanych źródeł.

Doświadczenia graniczne dzieci żydowskich wiązały się z permanentnym zagrożeniem ich życia (eksterminacją pośrednią i bezpośrednią, z „polowaniem na Żydów”45), z próbami adaptacji do przetrwania w dramatycznych warunkach, walką z głodem, chorobami, bezdomnością, skrajnym zmęczeniem i wyniszczeniem, strachem przed utratą najbliższych (lub ich brakiem) i pełnymi bardzo silnych emocji wspomnieniami okoliczności / miejsc śmierci najbliższych, z głębokim poczuciem samotności, tułaczką i doświadczaną na co dzień „pustynią ludzką". Barbara Engelking to ostatnie z doświadczeń opisuje w sposób następujący: „To egzystencjalne doświadczenie tułaczego losu jest

45 K. Budnicka, Dziewięć miesięcy pod ziemia, w: M. Łucyan, Dzieci getta. Ostatni świadkowie zagłady. Prawdziwe historie, Kraków 2021, s. 38-41; Z. Lubińska-Rosset, 11-letnia więźniarka polityczna, w: M. Łucyan, Dzieci getta. Ostatni świadkowie zagłady. Prawdziwe historie, Kraków 2021, s. 270-277. 
doznaniem pustyni ludzkiej zarówno w sensie dosłownym - braku pomocy, obijania się o ludzi i powtarzalnej, ciągłej konieczności dalszych zabiegów, jak też doznaniem ludzkiej pustyni w sensie psychologicznym - bezskutecznego poszukiwania zrozumienia, ale i wiary w drugiego człowieka. [...] To odtrącenie, odmowy, wyrzucanie, werbalne i niewerbalne komunikaty o strachu, zagrożeniu, niechęci i obojętności mogły skutkować nie tylko śmiercią fizyczną, lecz także psychiczną i duchową - utratą wiary, nadziei; rozpaczą. Pustynia ludzka to również doświadczenie wyrzucenia poza nawias człowieczeństwa, pozbawienie prawa przynależności do gatunku ludzkiego i prawa do braterstwa. Pustynia ludzka w wymiarze topograficznym to doświadczenie bezdomności. W wymiarze psychologicznym - doświadczenie osamotnienia i rozczarowania ludźmi, a w wymiarze duchowym - doznanie najgłębszego cierpienia"46.

W tej sytuacji istotnym warunkiem ocalenia był pewien rodzaj gry polegającej na ukrywaniu tożsamości, który obejmował zarówno działania instytucjonalne, jak i pozainstytucjonalne ${ }^{47}$.

Dramatyczne pytanie, przed którym stanęli żydowscy rodzice (i ich dzieci), było pytaniem o wybór (wartości) - o to, czy za wszelką cenę (cenę życia) podtrzymywać tożsamość prawdziwą, czy pozwolić na jej zerwanie i radykalną modyfikację, by ratować życie. Z jednej strony wielu z nich niechętnie przekazywało swoje dzieci Polakom chrześcijanom, ponieważ obawiało się, że zostaną one ochrzczone i przez to stracone dla judaizmu ${ }^{48}$. Z drugiej - coraz bardziej zdawali sobie sprawę, że właśnie taka swoista mimikra i zamiana figur (walencja lub konwersja religijno-kulturowa) stanowi najistotniejszy i niejednokrotnie

46 B. Engelking, „Jest taki piękny słoneczny dzień...” Losy Żydów szukających ratunku na wsi polskiej 1942-1945, Warszawa 2011, s. 55-56.

47 W. Kudyba, Gra i tożsamość. Dzieci żydowskie w Zakładzie dla Sierot Wojennych $w$ Turkowicach, w: Żydowskie dziecko, red. A. Jeziorkowska-Polakowska, A. Karczewska, Lublin 2013, s. 183.

48 R.C. Lukas, Dziecięcy płacz. Holokaust dzieci żydowskich i polskich $w$ latach 1939-1945, dz. cyt., s. 197. „Emmanuel Ringelblum, kronikarz warszawskiego getta, [...] podpisywał się pod mitem rozpowszechnianym wśród Żydów, że kościół katolicki wykorzystywał okazję związaną z ciężkim losem Żydów, aby pozyskiwać ich dzieci dla chrześcijaństwa". 
jedyny warunek ich ocalenia. Trudno opisać upór i determinację tych rodziców, którzy mimo przeżywanych lęków i wątpliwości podejmowali najróżniejsze próby ratowania swoich dzieci - np. narażając własne życie, „przemycali” je w walizkach, ukrywali w skrzyniach na węgiel z podwójnym dnem czy w grobowcach itp. Bywało, że chłopców przebierano za dziewczynki, ponieważ byli obrzezani ${ }^{49}$.

Później rodzice znikali z życia swoich dzieci, nie zostawiając im choćby imienia, zdjęcia czy pamiątki rodzinnej - małej cząstki wspomnienia o przodkach, którą mogłyby zachować w pamięci ${ }^{50}$. Maria Leszczyńska Ejzen uważa, że to „[...] poczucie ostatecznej zagłady kazało im zniknąć w niebycie, wykreślić siebie do końca, odciąć te dzieci od żydowskiego losu. Może idąc na śmierć, stracili ostatnią nadzieję, że będzie można nazywać się Rachela, Miriam, Aaron"51. Pod tym względem historie wielu dzieci ocalałych z Holocaustu są podobne; równocześnie jednak każda z nich jest jedyna w swoim rodzaju.

Dzieci żydowskie, które trafiały pod opiekę instytucji, placówek, organizacji świeckich czy rzymskokatolickich zakonów, jak również osób prywatnych, doznawały szybkiego i niezwykle intensywnego przebudowywania tożsamości ${ }^{52}$, o czym wspomina Ewa Kurek-Lesik ${ }^{53}$. „Między ich wejściem a wyjściem z klasztoru rozegrało się wiele tragedii,

49 K. Podolec, Dzieci Holocaustu. Utrata tożsamości i próby odnalezienia siebie, „Barbarzyńca. Pismo Antropologiczne”, 2005 nr 10, s. 56.

50 K. Budnicka, Dziewięć miesięcy pod ziemia, dz. cyt. s. 59. „To było polecenie. Odsunęła mnie od siebie i wskazała drogę. I poszłam. Uwierzyłam, że będzie dobrze, i poszłam. Rozstaliśmy się, choć dotychczas byłyśmy nierozłączne. Dziś wiem, że rodzice domyślali się. Co ich spotka. I chcieli, bym przeżyła... Ja natomiast na pewno nie zdawałam sobie sprawy z tego, że widzę ich ostatni raz. Że kilka słów wypowiedzianych w ciemności będzie pożegnaniem na całe życie. Ostatnim uściskiem, ostatnim pocałunkiem, ostatnią matczyną czułością".

51 M. Leszczyńska Ejzen, Jestem cała z tamtego świata, Łódź 1999, s. 36.

52 W. Theiss, Zniewolone dzieciństwo, dz. cyt., s. 24.

53 E. Kurek-Lesik, Gdy klasztor znaczył życie. Udziat żeńskich zgromadzeń zakonnych $w$ akcji ratowania dzieci żydowskich $w$ Polsce $w$ latach 1939-1945, Kraków 1992, a także: M. Leszczyńska Ejzen, Jestem cała z tamtego świata, dz. cyt., s. 221-222: „Ukrywane żydowskie dzieci musiały nauczyć się podstaw katolicyzmu, nie dla prozelityzmu, ale aby ułatwić ich ratowanie, ponieważ Niemcy często zatrzymywali podejrzanych młodych ludzi, szczególnie dziewczęta, i kazali 
zapadły życiowe decyzje, wystąpiły liczne rozczarowania i nadzieje. Dzieci, aby przeżyć Holocaust, musiały zerwać z całym swoim dotychczasowym światem, z pochodzeniem i religią" ${ }^{4}$, językiem, a zatem z tym wszystkim, co stanowiło podstawę ich tożsamości. Z chwili na chwilę musiały przestać być sobą i zacząć być kimś całkiem nowym. Otrzymywały nowe metryki urodzenia, „nowych rodziców”, nowe imiona i nazwiska; zmieniano w ich tożsamości wszystko, co mogło się wydać niebezpiecznie i podejrzane. Katarzyna Meloch komentuje to następująco: „Choć swój życiorys opowiadałam i opisywałam wiele razy, nigdy nie był to jeden i ten sam życiorys. Były różne. Zmiennych było wiele - data urodzenia, imiona rodziców, moje własne imię i na-

odmawiać im ważniejsze modlitwy katolickie. Podejrzanie wyglądający chłopiec musiał po prostu zdejmować spodnie".

${ }^{54}$ W. Theiss, Zniewolone dzieciństwo, dz. cyt., s. 24. Dwa zamieszczone poniżej cytaty ze wspomnień K. Budnickiej i M. Kalwary ukazują swoiste przejście ze świata kultury i religii żydowskiej do świata kultury i religii katolickiej; ta swoista mimikra kulturowo-religijna pozwoliła dzieciom przetrwać Zagładę: K. Budnicka, Dziewięć miesięcy pod ziemią, dz. cyt., s. 16-19: „[...] bardzo starannie przestrzegaliśmy zasad religii żydowskiej, obchodziliśmy wszystkie święta, każda sobota obowiązkowo wolna od pracy, szabat w gronie rodziny. [...] W każdy sobotni wieczór, gdy jeszcze nie wolno nam było zapalać światła - siedzieliśmy całą rodziną przy piecu kaflowym i tata opowiadał nam midrasze, czyli opowiadania biblijne. [...] Oczywiście przestrzegaliśmy koszerności. [...] Ze świąt dobrze pamiętam Chanukę z paleniem świeczek i piękną chanukiją, która stała w oknie naszego mieszkania. [...] Najbardziej uroczyste było oczywiście święto Pesach, czyli odpowiednik chrześcijańskich świąt Wielkiejnocy. To właśnie wtedy dom był pełen ludzi, a tata królował przy stole! Na koniec tego święta po brzegi wlewa się wino do kielicha Eliasza i otwiera się drzwi, by Eliasz mógł przez nie wejść. Wszyscy wpatrują się wtedy w kielich, czy Prorok coś z niego upije. Przyznam, że ten element przyprawiał mnie o ciarki na plecach. Bałam się, że rzeczywiście mógłby przyjść do nas i to wino wypić".

M. Kalwary, „Gudłaj, gudłaj, gudłaj!”, w: M. Łucyan, Dzieci getta. Ostatni świadkowie zagłady. Prawdziwe historie, Kraków 2021, s. 125: „Nie wiem, czy orientowali się w moim żydostwie, myślę, że tak. Choć ja skrupulatnie starałem się to ukryć. Codziennie wieczorem w swoim pokoiku na poddaszu przy celowo otwartych drzwiach klękałem i specjalnie głośno mówiłem pacierz, który już wcześniej wykułem na pamięć. Byłem pewny, że to słyszą, ale dziś myślę, że musieli sobie zdawać sprawę z ukrywania żydowskiego dziecka. Panowała jednak pełna konspiracja i nigdy tego tematu nie poruszali". 
zwisko, i oczywiście pochodzenie. Raz byłam Ireną Dąbrowską, innym razem Katarzyną Meloch. Irena została wymyślona po to, by Kasia mogła żyć. Miała nawet autentyczną metrykę wyciągniętą z kościoła na Targówku. Była ode mnie starsza o rok i oczywiście była ochrzczoną katoliczką. Panieńskie nazwisko jej matki to Gąska, imię Anna. Przez jakiś czas to wszystko odnosiło się do mnie. To był mój życiorys. Musiałam go znać na wyrywki, wejść w niego i zapomnieć o tym prawdziwym. Musiałam zapomnieć, że tak naprawdę urodziłam się nie w Warszawie, ale w Łodzi w 1932 roku w żydowskiej rodzinie. Musiałam zapomnieć o rodzicach, o tacie Maksymilianie i mamie Wandzie, których i tak od dawna nie widziałam. Już ich nie było, ale wtedy wierzyłam jeszcze, że są" 55 .

Ingerowano w semicki wygląd wielu dzieci żydowskich, ponieważ jeśli nie przebywały w ukryciu, stanowiły większe ryzyko niż te, które mogły uchodzić za Polaków. Najczęściej zmieniano im kolor włosów, by ich wygląd był bardziej „aryjski”. Krystyna Budnicka wspomina: „[...] mój wygląd szybko zdradzał pochodzenie. Miałam ciemne włosy i oczy i wyraźnie semickie rysy. Dlatego nie mogłam podróżować z odsłoniętą twarzą. Przed każdą zmianą miejsca bandażowano mi dokładnie głowę, tak by zakryć całą twarz i włosy. Odkryte było tylko jedno oko - żebym jednak coś widziała. Teoria był taka, że jestem ofiarą pożaru i zostałam ciężko poparzona. Tylko raz wyprowadzono mnie na ulicę nieco mniej zasłoniętą. Dzieci bawiące się na podwórku od razu zaczęły krzyczeć: «O! Patrzcie, Żydówka!». Nie wiem, skąd znały takie potworne słowo, ale musiały je usłyszeć od dorosłych. Opiekunka szybko pociągnęła mnie za rękę i tę noc spędziłam sama na węglu w piwnicy"56. Jeden z chłopców uratowanych z Zagłady pisał: „Bez przerwy pracowałem nad swoim wyglądem, ale nie mogłem zmienić koloru oczu ani ich smutnego wyrazu. Nie było też chirurgów plastycznych, którzy potrafiliby poprawić krzywiznę mojego nosa"57.

55 K. Meloch, Różne życiorysy, w: M. Łucyan, Dzieci getta. Ostatni świadkowie zagłady. Prawdziwe historie, Kraków 2021, s. 143.

56 K. Budnicka, Dziewięć miesięcy pod ziemia, dz. cyt., s. 67.

57 Y. Nir, The Lost Childhood: The Complete Memoir, C. Ozick (Introduction), Tucson, Arizona 2006, s. 184. 
Maria Kolankiewicz, dyrektorka Domu Małych Dzieci im księdza G.P.X. Baudouina w Warszawie, wspomina sposoby zacierania i ukrywania tożsamości dzieci żydowskich, które trafiały do tego zakładu za sprawą Ireny Sendlerowej: „Pani Irena Sendlerowa była jedną z tych osób, która przyprowadzała tu dzieci. Wyprowadzała dzieci z getta i szukając tutaj bezpiecznych miejsc po aryjskiej stronie, przyprowadzała je również do naszego domu. Naszym zadaniem tutaj, zadaniem pracowników tego domu, wówczas najistotniejszym, było dać tym dzieciom bezpieczeństwo. Czyli tak je nauczyć, takich zachowań, tak je wyżywić, żeby nie odróżniały się od pozostałych dzieci. Nauczyć tego, żeby wiedziały, jak brzmią ich nowe imiona. Żeby udawały, że są dziećmi katolickimi. Kiedy dziecko żydowskie trafiało do tego domu, jego tożsamość była całkowicie zacierana. Tutaj informacji o tym, że to było dziecko żydowskie, nie mogło być, bo to stwarzałoby zbyt duże ryzyko dla dziecka i dla zakładu. Natomiast chodziło też o to, aby pozostawić jakiś znak, który może być znakiem rozpoznawczym, że pod takim zapisem może ukrywać się dziecko żydowskie. Tym znakiem były nazwiska wpisane ołówkiem i nazwiska brane w cudzysłów"58. Sama zaś Irena Sendlerowa wspomina, że dzięki dużej odwadze i życzliwemu podejściu Jana Dobraczyńskiego do ratowania dzieci żydowskich i za jego podpisem na oficjalnym druku dzieci te trafiały do różnych zakładów jako polskie sieroty. W celu zatarcia śladów fałszowano wywiady i dane. Dzieciom zmieniano imiona, nazwiska i życiorysy, co całkowicie zmieniało ich sytuację, zapewniając im maksimum bezpieczeństwa jak na owe czasy ${ }^{59}$.

Analizowane wspomnienia dzieci Holocaustu ukazują nie tylko tragiczne wydarzenia z ich życia (i życia Żydów w ogóle), ale także ich myśli, uczucia, lęki i obawy. Autor powieści autobiograficznej Dziecko

58 Fragment wywiadu z M. Kolenkiewicz - dyrektorką Domu Małych Dzieci im księdza G.P.X. Baudouina w Warszawie, w: „Wróżka z Getta. Irena Sendlerowa Sprawiedliwa wśród Narodów Świata”, film dokumentalny, M. Nockowska (scenariusz i realizacja), M. Fijałkowski, K. Gromek (zdjęcia), Warszawa 2007.

59 W. Bartoszewski, Z. Lewinówna, Ten jest z ojczyzny mojej. Polacy z pomoca Żydom 1939-1945, Warszawa 2007, s. 102. Jan Dobraczyński w tamtym dramatycznym czasie był dyrektorem Referatu Opieki nad Dziećmi w Zarządzie Miasta Warszawy. 
Holocaustu pisze: „Wstydziłem się myśli, które przychodziły mi do głowy, [...] może Stasiek dobrze mówi, że Hitler to przyzwoity człowiek, który pragnie uszczęśliwić świat, dać ludziom maszyny, rowery, brukowane drogi. [...] Gdyby jeszcze pozwolił żyć mojemu narodowi... Ale nie pozwala. Zastanawiałem się dlaczego. Musi mieć jakiś powód. Nie zabija się przecież bez powodu. Więc może to wola boska [...] Myśmy zabili Jezusa, więc teraz Jezus zesłał mściciela. [...] Czy na pewno postępowanie Hitlera ma coś wspólnego ze śmiercią Jezusa? Może po prostu jesteśmy gorsi, niegodni [...]. Mówimy innym językiem, obchodzimy inne święta, w ogóle wszystko robimy inaczej [...]"60. W innym zaś miejscu dodaje: „Gdybym i ja był robakiem! Małym i paskudnym w gruncie rzeczy - byle nie Żydem. Chętnie zamieniłbym się w krowę, konia, ptaka na drzewie, ropuchę $\mathrm{w}$ stawie. W cokolwiek. Miałbym wtedy większe szanse przeżycia. Po co Bóg stworzył Żydów? Dla własnego widzimisię? Bo rozsądny powód chyba nie istnieje"61.

\section{Kilka uwag na zakończenie}

Całymi latami moje własne uczucia leżały uśpione jak skamielina wewnątrz paciorka bursztynu. Teraz, 50 lat od zakończenia wojny, pragnę odsłonić moją przeszłość i dowiedzieć się, kim byłam [...] $]^{62}$.

Powyższe analizy odsłaniają zapis „migawek” ze świata pełnego zła, nienawiści, grozy, przemocy, obezwładniającego strachu i lęku, trudnego do wytrzymania napięcia, w jakim żyły dzieci; opisy polowania na Żydów, bezdomności, tułaczki, głodu, wyniszczającej pracy fizycznej ponad dziecięce siły, dojmującej samotności, upokorzenia, ludzkiej zdrady, ukrywania się przed tzw. szmalcownikami, doświadczenia

60 J. Kuper, Dziecko Holocaustu, dz. cyt., s. 48-49.

61 Tamże, s. 64-65.

62 M. Winter, Trains. A Memoir of a Hidden Childhood during and after World War II, Jackson, Michigan 1997, s. 7. 
wspomnianej „pustyni ludzkiej”, na której dzieci napotykały jedynie oazy solidarności, altruizmu i współczucia ${ }^{63}$.

Nawet powrót do „swoich” bywał bardzo trudnym przeżyciem, ponieważ przez wiele lat wojny skutecznie wypierały świadomość tego, kim były. Zdarzało się, że nie znały ani prawdziwej daty, ani miejsca swoich urodzin; nie pamiętały także, kim byli i jak wyglądali ich rodzice. Ukrywając się pod przybraną tożsamością, wyparły / zapomniały to wszystko. W nowych tożsamościach, jakie im nadano, nie pozostał ślad po tym, co było przedtem, kim i jakie były. Chociaż udało się im przetrwać Zagładę, w przybranych tożsamościach czuły się tak, jakby nie żyły wcale, ponieważ nie były sobą i nie były „te same”; czuły się tak, jakby ich wcale nie było.

„Byłem jakby samotną wyspą, gorzej - cieniem, duchem albo nawet mniej niż cieniem czy duchem. Miałem wrażenie, że w ogóle mnie nie ma, albo że żyję w najlepszym razie plączę się między ludźmi jako czyjeś blade wspomnienie. Czasem jednak uświadamiałem sobie, że jestem zauważany. «Dlaczego nie umiesz po żydowsku?» - spytał pewien ciemnowłosy chłopak [...]. Na imię miał Motel, słyszałem, że był u partyzantów w lasach litewskich i dzięki temu ocalał [...]. «Umiałem, tylko zapomniałem» - odparłem uczciwie. [...] «Może nigdy nie umiałeś». «Ależ umiałem, naprawdę» - zapewniłem. «Bajeczki to opowiadaj swojej babci» warknął. Inni koledzy zaczęli również zadawać mi pytania. [...] Nocą słyszałem szepty na mój temat, w dzień wytykali mnie z daleka palcami. Jakiś malec przezwał mnie «Chrystusikiem» i przezwisko natychmiast się przyjęło. Chudzielec o migdałowych oczach zarzucił mi, że jestem szpiegiem. [...] wpadłem na pewną myśl. Może koledzy mają rację. Może nie jestem Żydem i przeżyłem tylko dlatego, że w rzeczywistości jestem katolikiem"64.

W przypadku tożsamości dzieci ocalonych z Holocaustu zabrakło zatem poczucia temporalnej ciągłości (związku między tym, kim były w przeszłości, i tym, kim są teraz, oraz antycypowaną przyszłością własną), na pozostawanie ciągle tym samym, bycie kimś, kto jest toż-

63 R. Szuchta, „Spotkani na drodze” w doświadczeniu dzieci żydowskich ukrywajacych się na polskiej wsi w trzeciej fazie zagłady (1942-1945), dz. cyt., s. 161-175.

64 J. Kuper, Dziecko Holocaustu, dz. cyt., s. 283-284. 
samy z sobą z przeszłości - ze swoimi przeszłymi wartościami, myślami, działaniami. Wielu ocalonych czuło, że ich tożsamość jest rozdarta między przeszłością a teraźniejszością. Nie ma w niej miejsca na zaspokojenie potrzeby przynależenia, bliskości, poczucia więzi, zakorzenienia, stabilności, identyfikacji z dziedzictwem, dorobkiem przodków (kulturą duchową i materialną, językiem, religią itp.). Tożsamość człowieka kształtuje przede wszystkim dzieciństwo, miejsce urodzenia, najbliżsi. Innymi słowy, nasze „korzenie” są fundamentem tego, kim jesteśmy. Tożsamość mająca swój początek w dzieciństwie osadza człowieka / dziecko w konkretnym miejscu, czasie i w konkretnych więziach społeczno-historycznych; to ona stanowi o jego stabilizacji, zapewnia mu poczucie bezpieczeństwa, które umożliwia konfrontację $\mathrm{z}$ innymi i światem. To $\mathrm{w}$ tożsamości kształtuje się poczucie moralności dziecka, zapisuje się to, co jest dla niego ważne.

Tymczasem dla większości dzieci żydowskich, które przeżyły Zagładę, dla dzieci „bez dzieciństwa”, dzieci „oderwanych od własnych korzeni", walka o siebie i swoją tożsamość trwa(ła) w zasadzie przez całe życie. Wydaje się także, że pozbawienie dzieci ocalałych z Holocaustu tożsamości przez jej zerwanie i radykalną przebudowę, objawiające się wspomnianym brakiem odniesienia oraz wewnętrzną pustką, sprawiło, że ich powrót „do siebie” odbywał się każdego dnia i w każdej fazie ich życia.

„Moja droga do normalności była długa i ciężka. Nie miałam rodziny, która by mnie wspierała w psychicznym dochodzeniu do siebie, więc mogłam liczyć na siebie i moje opiekunki, a te, jak wiadomo, pod swoimi skrzydłami miały też kilkanaścioro innych dzieci. Długo po wojnie chciałam być niewidzialna. Trochę jakbym przepraszała, że żyję. Starałam się być bardzo pomocna, nie sprawiać najmniejszych problemów. Dziś myślę, że miałam bardzo głęboko zakorzeniony strach przed odrzuceniem. Jednocześnie czułam potrzebę oddania tego, co dostałam od ludzi. Jakbym miała do spłacenia dług"65 - stwierdza Krystyna Budnicka.

${ }^{65}$ K. Budnicka, Dziewięć miesięcy pod ziemia, dz. cyt., s. 72. 
W kontekście przywoływanych wspomnień dzieci Holocaustu zerwanie, wykorzenienie, „rozdwojenie” tożsamości będące w czasach Zagłady warunkiem przeżycia, ujawnia granicę, na której wyczerpuje się kluczowa dla współczesnej pedagogiki prawomocność negatywnej waloryzacji przemocy symbolicznej. W czasach tych przemoc symboliczna mogła bowiem ratować życie.

Holocaust w całej swojej tragicznej postaci jest przykładem, w jaki sposób, nawet w obliczu śmierci, ludzie mogą opierać się sile dążącej do ich unicestwienia. Z drugiej jednak strony - wydaje się, że dzieci żydowskie, które go przeżyły, do końca życia dźwigały potężny bagaż pytań tożsamościowych, pozostających najczęściej bez odpowiedzi: „Kim jestem?”, „Kim byli i jak wyglądali moi rodzice i bliscy?”, „Gdzie jest miejsce, z którego pochodzę?" itp.

Maria Leszczyńska Ejzen, odnosząc się do swojej przeszłości, tak oto komentuje teraźniejszość: „[...] zastanawiam się czasem, jak mogę śmiać się i całować, gadać głupstwa i płakać z głupich powodów! - Jestem cała z tamtego świata, wstałam z grobu pełnego trupów i żyję jak inni ludzie. Czy mogę?"66.

\section{Bibliografia}

Babiński, Grzegorz. Metodologiczne problemy badań etnicznych. Kraków: Zakład Wydawniczy Nomos, 1998.

Babiński, Grzegorz. Pogranicze polsko-ukraińskie. Etniczność, zróżnicowanie religijne, tożsamość. Kraków: Zakład Wydawniczy Nomos, 1997.

Bandura, Ludwik. Wpływ wojny na psychikę dzieci i młodzieży (fragmenty z rozprawy doktorskiej z 1950 roku), wstęp i oprac. Zbigniew Kwieciński. Toruń: Wydawnictwo Uniwersytetu Mikołaja Kopernika, 2004.

Bartoszewski, Władysław. Lewinówna, Zofia. Ten jest z ojczyzny mojej. Polacy z pomoca Żydom 1939-1945. Warszawa: Świat Książki, 2007.

Bauman, Zygmunt. „Ponowoczesne wzory osobowe”. Studia Socjologiczne nr 2(200) (1993): 7-31.

${ }^{66}$ M. Leszczyńska Ejzen, Jestem cała z tamtego świata, dz. cyt., s. 14-15. 
Bauman, Zygmunt. „Tożsamość jaka była, jest i po co?”. W: Wokót problemów tożsamości, red. Aldona Jawłowska, 8-25. Warszawa: Wydawnictwo LTW, 2001.

Berger, Peter L. Zaproszenie do socjologii. Warszawa: Państwowe Wydawnictwo Naukowe, 1988.

Berger, Peter L. Luckmann, Thomas. Społeczne tworzenie rzeczywistości. Warszawa: Państwowy Instytut Wydawniczy, 1983.

Dynin, Jerzy. Aryjskie papiery. Warszawa: Prószyński Media, 2019.

Dzieci oskarżają, red. Maria Hochberg-Mariańska, Noe Gruss. Kraków-Łódź-Warszawa: Wiedza Powszechna, 1947.

Dziennik Anny Frank. Warszawa: Państwowy Instytut Wydawniczy, 1957.

Engelking, Barbara. „Jest taki piękny słoneczny dzień...” Losy Żydów szukających ratunku na wsi polskiej 1942-1945. Warszawa: Stowarzyszenie Centrum Badań nad Zagładą Żydów, 2011.

Fink, Ida. Skrawek czasu. Londyn: „Aneks”, 1987.

Fragment wywiadu z M. Kolenkiewicz - dyrektorką Domu Małych Dzieci im księdza G.P.X. Baudouina w Warszawie. W: „Wróżka z Getta. Irena Sendlerowa Sprawiedliwa wśród Narodów Świata", film dokumentalny, M. Nockowska (scenariusz i realizacja), M. Fijałkowski, K. Gromek (zdjęcia). Warszawa 2007.

Goffman, Erving. Piętno. Rozważania o zranionej tożsamości, tłum. Aleksandra Dzierżyńska, Joanna Tokarska-Bakir. Gdańsk: Gdańskie Wydawnictwo Psychologiczne, 2005.

Grądzka, Martyna. „Utracone dzieciństwo. Dziecko żydowskie w KL Płaszów”. W: Żydowskie dziecko, red. Anna Jeziorkowska-Polakowska, Agnieszka Karczewska, 171-182. Lublin: Towarzystwo Naukowe KUL Jana Pawła II, 2013.

Grzegorczyk, Andrzej. Filozofia czasu próby. Paryż: Editions du Dialogue, 1979. Hilberg, Raul. Sprawcy. Ofiary. Świadkowie. Zagłada Żydów 1933-1945, tłum. Jerzy Giebułtowski. Warszawa: Wydawnictwo Cyklady, 2007.

Jawłowska, Aldona. „Tożsamość na sprzedaż”. W: Wokół problemów tożsamości, red. Aldona Jawłowska, 51-78. Warszawa: Wydawnictwo LTW, 2001.

Key, Ellen K. Stulecie dziecka. Warszawa: Wydawnictwo Dwie Siostry, 2006.

Kudyba, Wojciech. „Gra i tożsamość. Dzieci żydowskie w Zakładzie dla Sierot Wojennych w Turkowicach". W: Żydowskie dziecko, red. Anna Jeziorkowska-Polakowska, Agnieszka Karczewska, 183-189. Lublin: Towarzystwo Naukowe KUL Jana Pawła II, 2013. 
Kuper, Jack. Dziecko Holocaustu. Warszawa: Państwowy Instytut Wydawniczy, 1995.

Kurek-Lesik, Ewa. Gdy klasztor znaczył życie. Udział żeńskich zgromadzeń zakonnych $w$ akcji ratowania dzieci żydowskich $w$ Polsce $w$ latach 1939-1945. Kraków: Wydawnictwo Znak, 1992.

Leociak, Jacek. Teksty wobec zagłady. (O relacjach z getta warszawskiego). Wrocław: Wydawnictwo „Leopoldinum”, 1997.

Leszczyńska Ejzen, Maria. Jestem cała z tamtego świata. Łódź: Oficyna Bibliofilów, 1999.

Lukas, Richard C. Dziecięcy płacz. Holokaust dzieci żydowskich i polskich $w$ latach 1939-1945, tłum. Tomasz Kazimierczak. Poznań: Wydawnictwo Replika, 2018.

Łucyan, Magda. Dzieci getta. Ostatni świadkowie zagłady. Prawdziwe historie. Kraków: Wydawnictwo Znak Horyzont, 2021.

Malik, Ewelina. „Doświadczenie graniczne utrwalone na kartach dzienników dzieci żydowskich”. W: Dzieci wojny, red. Alicja Bartuś, 177-187. Oświęcim: Państwowe Muzeum Auschwitz-Birkenau, 2016.

Mause, Lloyd de. „The History of Childhood as the History of Child Abuse". Aesthema: The Journal of the International Primal Association No. 11 (1994): 48-62.

Nikitorowicz, Jerzy. Pogranicze. Tożsamość. Edukacja międzykulturowa. Białystok: Trans Humana Wydawnictwo Naukowe, 1995.

Nir, Yehuda. The Lost Childhood: The Complete Memoir, Cynthia Ozick (Introduction). Tucson, Arizona: Schaffner Press, 2006.

Pamiętnik Dawida Rubinowicza. Warszawa: Książka i Wiedza, 1960.

Podolec, Katarzyna. „Dzieci Holocaustu. Utrata tożsamości i próby odnalezienia siebie". Barbarzyńca. Pismo Antropologiczne nr 10 (2005): 56-58.

Smolińska-Theiss, Barbara. „Pedagogika pokoju”. W: Pokój z dziećmi. Pedagogika chrześcijańska wobec zagrożeń rozwoju dziecka, red. Barbara Smolińska-Theiss, 7-10. Warszawa: Wydawnictwo Akademickie „Żak”, 1999.

Starnawski, Marcin. Socjalizacja i tożsamość żydowska w Polsce powojennej. Narracje emigrantów z pokolenia Marca' 68. Wrocław: Wydawnictwo Naukowe Dolnośląskiej Szkoły Wyższej, 2016.

Szuchta, Robert. „«Spotkani na drodze» w doświadczeniu dzieci żydowskich ukrywających się na polskiej wsi w trzeciej fazie zagłady (1942-1945)". W: Dzieci wojny, red. Alicja Bartuś, 161-175. Oświęcim: Państwowe Muzeum Auschwitz-Birkenau, 2016. 
Śmigły, Mateusz. Bezwartościowe rasowo dzieci, https://en.tropicielehistorii. pl/bezwartosciowe-rasowo-dzieci-2/\#.YI16qz9R2Uk (dostęp: 25.04.2021).

Theiss, Wiesław. „Sieroctwo wojenne polskich dzieci (1939-1945). Zarys problematyki". Przegląd Pedagogiczny nr 1(21) (2012): 79-95.

Theiss, Wiesław. Zniewolone dzieciństwo. Warszawa: Wydawnictwo Akademickie „Żak”, 1996.

Tych, Feliks. „Przedmowa”. W: Archiwum Ringelbluma. Konspiracyjne Archiwum Getta Warszawy, t. 2: Dzieci - tajne nauczanie w getcie warszawskim, red. Ruta Sakowska, V-VIII. Warszawa: Wydawnictwa Uniwersytetu Warszawskiego, 2000.

Warmińska, Katarzyna. Tatarzy polscy. Tożsamość religijna i etniczna. Kraków: Wydawnictwo Universitas, 1999.

Winter, Miriam. Trains. A Memoir of a Hidden Childhood during and after World War II. Jackson, Michigan: Kelton Press, 1997.

Wróblewska, Monika. „Kształtowanie osobowości w perspektywie rozwojowej i edukacyjnej". Pogranicze. Studia Społeczne t. 17 (2011): 176-187.

Znaniecki, Florian. Nauki o kulturze: narodziny i rozwój. Warszawa: Państwowe Wydawnictwo Naukowe, 1971. 